\title{
Natural History Calendar
}

JANUARY

Coldest month

Cardinals begin to sing

Bald Eagles nest

Wintering butterflies appear at early flowering shrubs

Live Oak Caterpillars appear in the oaks

FEBRUARY

Spring is in the air

First Purple Martins return

Redbud trees flower

First neotropical migrants appear

Spanish Daggers bloom

Crane Flies appear

Huisache trees flower in mass

MARCH

Days usually are warm and sunny

Ruby-throated Hummingbirds appear

Cliff Swallows return to nest sites

Scissor-tailed Flycatchers return

Spring solstice

Robin and Waxwing flocks pass through

Striped Skunks start hunting mates

Neotropical migrants increase

[xiii ] 
[ xiv * NATURALLY . . SOUTH TEXAS

Bald Eagles head north

Watch out for chiggers

APRIL

Wildflowers peak

Whooping Cranes leave Aransas, heading north

Neotropical migrants continue to increase

Chimney Swifts return to our neighborhoods

First fireflies are active during evening hours

Mesquite leaves green up

MAY

Northbound migrants peak the first few days

Retamas produce bright yellow flowers

Barred Owl youngsters are out and about

Annual Neotropical Migrant Count

Yellow-billed Cuckoo calls are commonplace

Camel Crickets can be abundant

IUNE

Copperheads are again out and about

Bald Cypress trees are in full summer dress

Painted Buntings are commonplace

Crested Caracara young are in training

Longest day of the year

Wood Storks appear in our wetlands

jULY

Thunderstorms can be expected

Aransas and Victoria July 4 butterfly counts

Early southbound shorebirds appear

Wild grapes ripen and are eaten by wildlife and humans

Daddy Longlegs come out of hiding

AUGUST

Hottest month

Garden spiderwebs become numerous 
Praying Mantises increase

Mississippi Kites appear over our towns

Fairy rings arise after each storm

Southbound migrants increase

Tropical storms are possible

SEPTEMBER

Wettest month

Field Crickets can be abundant

Southbound Ruby-throated Hummingbirds are everywhere Bald Eagles return to their nesting grounds

Last of the Ruby-throated Hummingbirds move south

Eastern Phoebes return for the winter months

Significant hawk migration gets underway

OCTOBER

Peregrine Falcons return

Leafcutter Ants are especially active

Monarch Butterflies are migrating south en masse

Sandhill Cranes begin to arrive

Flocks of American White Pelicans appear in the skies

Red Admiral Butterflies appear

NOVEMBER

Cooling trend noticeable

Numbers of Snow and White-fronted Geese appear

Early Whooping Cranes arrive at Aransas

"Butter-butts" return for the winter

Fall color appears on a few oaks and other broadleaf trees

Red berries appear on several shrubs

DECEMBER

Holiday spirit prevails

Winter solstice

Christmas Bird Counts dominate the last days of the month 
This page intentionally left blank 